\title{
Caffeinated instant coffee prevents an increase in exercise-mediated superoxide anion production in rat peritoneal neutrophils
}

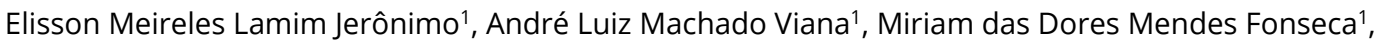
Marilene Lopes Ângelo ${ }^{1}$, Bruno Cesar Correa Salles ${ }^{1}$, Stella Maris da Silveira Duarte ${ }^{1}$ (1), Sônia Aparecida Figueiredo ${ }^{1}$ (D), Maria Rita Rodrigues ${ }^{1}$ (D), Fernanda Borges de Araújo Paula ** (i)

'Departamento de Análises Clínicas e Toxicológicas, Faculdade de Ciências Farmacêuticas, Universidade Federal de Alfenas, Alfenas, Minas Gerais, Brasil

*Corresponding author: fernandabap0@gmail.com

\begin{abstract}
The present study analyzed the in vivo effects of drinking caffeinated and decaffeinated instant coffee $(8 \% \mathrm{w} / \mathrm{v})$ by adult male Wistar rats submitted to high-intensity exercises. The parameters used in the evaluation were the determination of the activities of NADPH oxidase, myeloperoxidase and other antioxidant enzymes present in neutrophils of rats. It was observed that exercise-induced superoxide anion production depends on the NADPH oxidase activity (estimated by the cytochrome $C$ reduction test) in peritoneal neutrophils $(p<0.05)$. The intake of caffeinated and decaffeinated instant coffee beverages and of a caffeine solution to $1.67 \%$ did not induced changes in the activities of the enzymes myeloperoxidase, superoxide dismutase and glutathione peroxidase $(p<0.05)$. But consumption of caffeinated instant coffee drink prevented an increase in NADPH oxidase-mediated superoxide production induced by highly intense exercise in rat neutrophils. While the decaffeinated instant coffee drink or caffeine solution alone did not affect NADPH oxidase-mediated superoxide production. We suggest that this activity is associated with the chemical composition and concentration of phenolic compounds and other antioxidant substances formed during roasting. From the obtained results, it was concluded that moderate intake of caffeinated instant coffee (equivalent to a daily human consumption of $450-\mathrm{mL}$ cups of coffee) may have beneficial effects on health, contributing to a reduction in superoxide anion generation. Therefore, more research must be conducted to elucidate the mechanism of action of caffeinated coffee on NADPH oxidase in neutrophils.
\end{abstract}

Keywords: Coffee. NADPH Oxidase. Oxidative Burst. Caffeine. Antioxidant. Exercise.

\section{How to cite}

Jerônimo EML, Viana ALM, Fonseca MDM, Ângelo ML, Salles BCC, Duarte SMS, Figueiredo SA, Rodrigues MR, Paula FBA. Caffeinated instant coffee prevents an increase in exercise-mediated superoxide anion production in rat peritoneal neutrophils. Rev Ciênc Farm Básica Apl.

2020;41:e673. https://doi.org/10.4322/2179-443X.0673

\section{INTRODUCTION}

Coffee is currently recognized as a super functional food, a fact that adds value to the traditional consumption of the beverage by people of all social classes, including athletes. For 
this reason it is one of the most consumed beverages worldwide (Dallo, 2009; Kwak et al., 2017; Olas \& Bryś, 2019; Pereira et al., 2020).

Coffee is known to be a stimulant, a property mainly attributed to caffeine, but many components in coffee may be considered bioactive, such as diterpenes (cafestol and kahweol), caffeic acid, phenolic compounds (chlorogenic acids, cafestol, kahweol and polyphenols), alkaloids (caffeine and trigonelin) and other secondary metabolites. Therefore, there is growing interest in the effects of this beverage on health (Parras, et al., 2007; Lattanzio et al., 2009; Frost-Meyer \& Logomarsino, 2012; Kwak et al., 2017; Kalschne et al., 2019; Stefanello et al., 2019; Pereira et al., 2020).

The effects of regular coffee consumption on prevention of diseases or pathological process related to oxidative stress such as inflammation, cardiovascular disorders, diabetes, cancer, hepatic injury and cirrhosis have been demonstrated in several studies to be a functional beverage (Frost-Meyer \& Logomarsino, 2012; Moreira et al., 2013; O'Keefe et al., 2013; Kalschne et al., 2019; Stefanello et al., 2019; Pereira et al., 2020).

The antioxidant activity of coffee bioactives such as caffeine promotes the reduction of degradation of DNA, hydroxyl radicals and inflammatory cytokines. Chlorogenic acid acts to protect DNA, increases the level of glutathione, improves the activity of glutathione reductase and provides a reduction in body weight and fat mass. The antioxidant compounds in coffee increase the ability to eliminate free radicals and reactive oxygen species, with a consequent reduction in lipid peroxidation (Frost-Meyer \& Logomarsino, 2012; Stefanello et al., 2019).

Antioxidant compounds are able to significantly delay or inhibit ROS oxidation. Endogenous antioxidants, enzymatic or non-enzymatic, play an important role in the body's first line of defense against oxidative stress. The main enzymatic antioxidants are: superoxide dismutase (SOD), catalase (CAT), glutathione peroxidase (GPX), glutathione reductase (GR) and peroxiredoxins (Prxs). These enzymes act on the superoxide anion (superoxide dismutase), on hydrogen peroxide, producing water (glutathione catalase peroxidase) and on the oxygen molecule (catalase). The second line of defense is performed by non-enzymatic antioxidants (glutathione, uric acid, coenzyme Q, lipoic acid) that act to inactivate radicals and oxidants. Finally, the third line of defense works to repair damaged biomolecules before their buildup accumulation can result in changes in cell metabolism (Luczaj et al., 2017; MirończukChodakowska et al., 2018; Warraich et al., 2020).

Dietary antioxidants such as vitamin E, vitamin C, carotenoids, minerals ( $\mathrm{Zn}, \mathrm{Mn}, \mathrm{Cu}, \mathrm{Se}$ ) and polyphenols can act in synergy with endogenous antioxidants and contribute to homeostasis and, consequently, in the restoration of health. Exogenous antioxidants are found in fruits, vegetables, cereals and drinks like coffee (Mirończuk-Chodakowska et al., 2018).

Regular physical training also helps restore health, favoring an increase in life expectancy and a reduction in risk factors. However, exceeding the recommended limits through intense sports or exercise can cause muscle microtrauma (Margonis et al., 2007; da Silva et al., 2020). Tissue damage resulting from acute or chronic exercise leads to an inflammatory response involving leukocyte infiltration into skeletal muscle, which can induce a secondary injury in which oxidative stress might be involved. Reduced nicotinamide adenine dinucleotide phosphate (NADPH) oxidases present on the cell surface of activated neutrophils form an active enzyme complex that catalyzes the production of reactive oxygen species (ROS), such as superoxide $\left(\mathrm{O}^{2-}\right)$, which can be reduced to hydrogen peroxide $\left(\mathrm{H}_{2} \mathrm{O}_{2}\right)$. Hydrogen peroxide may be converted to hypochlorous acid by myeloperoxidases present in neutrophils, resulting in oxidative stress (Babior, 2000; Ciz et al., 2012; Kain \& Halade, 2020). Therefore, the activation of an antioxidant defense system during and after physical exercise is important to avoid oxidative injury and exert additional anti-inflammatory actions (Powers \& Jackson, 2008; Limón-Pacheco \& Gonsebatt, 2009; Ruangthai \& Phoemsapthawee, 2019).

In different studies with coffee, a reduction in the concentration of malondialdehyde has been observed in various organs in animals and in human plasma (Rocha et al., 2010; Carvalho et al., 2011; Kotyczka et al., 2011; Viana et al., 2012). However, literature data have demonstrated that this effect may vary not only with the species of coffee tree studied but 
also according to how the coffee beans were obtained and roasted and the method used to prepare the beverage (Toci et al., 2006; Duarte et al., 2009; Tripetch \& Borompichaichartkul, 2019). Another factor that can contribute to these effects is the storage time of the grains. Prolonged storage can alter the qualitative and quantitative composition of bioactive substances in coffee (Tripetch \& Borompichaichartkul, 2019).

Some authors attribute the antioxidant activity of coffee to its caffeine content (Vignoli et al., 2011). However, other compounds present in coffee can also act as antioxidants, such as chlorogenic acid, trigonelline, melanoidins, diterpenes and Maillard reaction products (Brezová et al., 2009; Liu \& Kitts, 2011; Kalschne et al., 2019). Viana et al. (2012) demonstrated that the intake of caffeinated instant coffee was able to reduce lipid peroxidation and protein oxidation induced by intense exercise in the anterior tibialis muscles of rats, but neither decaffeinated instant coffee nor caffeine solution showed antioxidant activity in vivo. Other substances present in coffee may be responsible for the protective and inducing effects of the endogenous antioxidant system (Stefanello et al., 2019).

Despite studies showing the antioxidant properties of coffee, few have examined the effect of coffee consumption on the oxidative burst, one of the main events that lead to cell activation and increased oxidative processes in the body. Thus, the aim of this study was to analyze the possible in vivo effects of drinking caffeinated and decaffeinated instant coffee on oxidative burst and on the enzyme activities of the components of the antioxidant defense system in the neutrophils of rats subjected to intense exercise.

\section{MATERIALS AND METHODS}

\subsection{Obtaining coffee samples and preparation of the beverage}

Samples of caffeinated instant coffee and decaffeinated instant coffee of the Spressos Melitta ${ }^{\circledR}$ brand were purchased from a local trader in Alfenas-MG. Theses coffees correspond to a combination of $100 \%$ Arabica beans. Coffee drinks were prepared according to the instructions on the package.

\subsection{Experimental groups}

The study was performed in accordance with the ethical principles outlined for animal experimentation adopted by the Brazilian College of Animal Experimentation and received approval from the Ethics Committee on Animal Research of Federal University of Alfenas (Unifal-MG), Alfenas, Minas Gerais, Brazil (protocol no 117/2007). Sixty-four adult male Wistar rats (Rattus norvegicus) weighing $270 \pm 20 \mathrm{~g}$ were obtained from the Unifal-MG vivarium. The animals were maintained in a temperature-controlled room under a $12 \mathrm{h:12} \mathrm{h}$ artificial light/dark cycle with food and water ad libitum access.

The rats were divided into 8 groups containing 8 animals in each: animals group not subjected to intense exercise and treated with water (control group); animals group subjected to intense exercise and treated with water (Exer); animals received caffeinated instant coffee and not subjected to intense exercise (CC); animals received decaffeinated instant coffee and not subjected to intense exercise $(C D)$; animals treated with caffeine solution and not subjected to intense exercise (CF); animals treated with caffeinated instant coffee and subjected to intense exercise (Exer.CC); animals treated with decaffeinated instant coffee and subjected to intense exercise (Exer.CD); and animals treated with caffeine solution and subjected to intense exercise (Exer.CF).

Coffee Drink and Caffeine Administration: Freshly prepared coffee $(8 \% \mathrm{w} / \mathrm{v})$ was administered daily to animals by gavage ( $3.8 \mathrm{~mL} / \mathrm{kg}$ body weight) corresponding to $280 \mathrm{mg} / \mathrm{kg}$ body weight for 21 days, equivalent to a daily human consumption of $450-\mathrm{mL}$ cups of coffee. Caffeine powder was used to prepare the caffeine solution $(1.67 \% \mathrm{w} / \mathrm{v})$ in water at $90^{\circ} \mathrm{C}$. The caffeine solution and the water were administered to animals by gavage for 21 days, once per day at $6 \mathrm{mg} / \mathrm{kg}$ body weight and $3.8 \mathrm{~mL} / \mathrm{kg}$ body weight, respectively. This amount was chosen 
based on the caffeine content in samples of Brazilian instant coffee and the optimum amount suggested to improve physical performance, which is 3 to $6 \mathrm{mg} / \mathrm{kg}$ of pure caffeine (Ramalakshmi \& Raghavan, 1999). The animals were supplied with commercial NuvilabCr-1 ${ }^{\circledR}$ (Nuvital Nutriente S/A, Colombo, PR, Brazil) and water ad libitum throughout the treatment period.

Intense Exercise Protocol: At the end of 19 days, animals from the Exer, Exer.CC, Exer.CD and Exer.CF groups were exercised using functional electrical stimulation to produce standardized repetitive activation of the fast anterior tibialis muscle, according to the method of Paula et al. (2005). The functional electrical stimulations (FES) were performed on the anterior tibialis muscle at $100 \mathrm{~Hz}$ with a 1:1 On-Off cycle (10 s contraction and $10 \mathrm{~s}$ rest) for 15 min using an Electrostimulator Kinesis Clinical apparatus (model Kinesis New Microcontrolled $^{\circledR}$, KW Industry National Electronic Technology Ltda).

\subsection{Obtaining serum and neutrophils samples}

At the end of 21 days of treatment with coffee or caffeine-containing drinks, all animals were anesthetized and blood samples were collected by cardiac puncture. The blood was centrifuged at $2,500 \mathrm{~g}$ for $10 \mathrm{~min}$ to obtain serum for creatine kinase (CK) activity determination. Rat neutrophils were obtained by intraperitoneal lavage with $20 \mathrm{~mL}$ of phosphate-buffered saline (PBS) $6 \mathrm{~h}$ after an intraperitoneal injection of $2 \mathrm{~mL}$ of a $12 \%(\mathrm{w} / \mathrm{v})$ sterile sodium caseinate solution $\left(\mathrm{Sigma}^{\circledR}\right)$ in saline. After a gentle massage of the abdomen, the cell suspension was collected by aspiration with a syringe containing a $40 \times 12 \mathrm{~mm}$ needle (Ferreira et al., 2012).

\subsection{Preparation of neutrophil suspension}

The cell suspension was centrifuged at $4^{\circ} \mathrm{C}(500 \mathrm{~g}$ for $10 \mathrm{~min})$. The number of viable cells (> 95\% neutrophils) was determined by Trypan blue exclusion in a Neubauer chamber (Knittel Glaser, Braunschweig, Germany) under an optical microscope. The differential cell count was performed after fixation and May-Grunwald-Giemsa staining. The cell suspensions were used to determine NADPH oxidase and myeloperoxidase activities (Ferreira et al., 2012).

\subsection{Preparation of neutrophil homogenates}

After the addition of $1 \%$ Triton X-100 solution, the cell suspensions were lysed by freezing and thawing and then submitted to centrifugation at 5,000 $\mathrm{g}$ for 10 minutes. This procedure disrupted nearly $100 \%$ of the cells. The supernatant was used to determine the activities of superoxide dismutase (SOD) and glutathione peroxidase (GPx) (Oyanagui, 1984; Sinet et al., 1975).

\subsection{Creatine kinase activity}

CK activity in animal serum was determined using the kinetic method at $340 \mathrm{~nm}$. The procedure was based on the conversion of creatine phosphate and adenosine diphosphate to creatine and adenosine triphosphate, respectively. The results were expressed in $\mathrm{U} / \mathrm{L}$, where $1 \mathrm{U}$ is equivalent to the amount of $\mathrm{CK}$ that resulted in the phosphorylation of $1 \mathrm{mmol}$ of creatine per min at $37^{\circ} \mathrm{C}$ (Burtis et al., 2008).

\subsection{Burst respiratory evaluation}

\subsubsection{NADPH oxidase system activity (Cytochrome $C$ reduction test)}

The production of superoxide anions by NADPH oxidase in neutrophils was monitored by the reduction of cytochrome $\mathrm{C}$ (Cyt $\mathrm{C})$. The test was conducted in a plastic bucket containing $1 \times 10^{6}$ neutrophils per milliliter, $100 \mu \mathrm{mol} . \mathrm{L}^{-1}$ cytochrome $\mathrm{C}$, and $20 \mu \mathrm{g} \cdot \mathrm{mL}^{-1}$ catalase in PBS 
containing $10 \mathrm{mmol} . \mathrm{L}^{-1}$ glucose $\left(\mathrm{pH}\right.$ 7.4). The buckets were maintained at $37^{\circ} \mathrm{C}$ for $10 \mathrm{~min}$ in a spectrophotometer to equilibrate the system. Superoxide production was initiated by the addition of PMA (12-myristate 13-acetate phorbol) $\left(100 \mathrm{ng} \cdot \mathrm{mL}^{-1}\right)$. After the addition of Phorbol12-Myristate-13-Acetate (PMA), the reaction was monitored by spectrophotometry for $3 \mathrm{~min}$ at a wavelength of $550 \mathrm{~nm}$ (Jones \& Hancock, 1994)

\subsubsection{Myeloperoxidase Assay (HOCl formation)}

Peritoneal neutrophils $\left(1.0 \times 10^{6} / \mathrm{mL}\right)$ were incubated with $12 \mathrm{mM}$ taurine in a $10 \mathrm{mM}$ phosphate buffer (pH 7.4) containing $140 \mathrm{mM} \mathrm{NaCl}, 10 \mathrm{mM} \mathrm{KCl}, 0.5 \mathrm{mM} \mathrm{MgCl}_{2}, 1 \mathrm{mM} \mathrm{CaCl}$ and $1 \mathrm{mg} / \mathrm{mL}$ glucose. After $10 \mathrm{~min}$ of preincubation at $37^{\circ} \mathrm{C}$, cells were stimulated with $100 \mathrm{ng} / \mathrm{mL}$ PMA. After $30 \mathrm{~min}$, the reactions were stopped by adding $20 \mathrm{~g} / \mathrm{mL}$ catalase and placing the tubes in melting ice for $5 \mathrm{~min}$. Cells were pelleted by centrifugation (10 $\mathrm{min}$ at $\left.12,000 \mathrm{~g}, 4^{\circ} \mathrm{C}\right)$. The concentration of accumulated taurine chloramine present in the supernatants was measured by the oxidation of TNB to 5,5-dithiobis(2-nitrobenzoic acid) (DTNB). The decrease in TNB absorbance was measured at $412 \mathrm{~nm}$ as previously described (Kettle \& Winterbourn, 1994).

\subsection{Antioxidant enzyme activity}

\subsubsection{Superoxide dismutase activity (SOD)}

SOD activity in homogenates was quantified according to the reduction of cytochrome $c$ method described by Vilela et al. (2012). One unit of SOD activity was defined as the amount of SOD sufficient to inhibit the rate of reduction of cytochrome $\mathrm{C}$ by $50 \%$.

\subsubsection{Glutathione peroxidase activity (GPX)}

The GPx activity was measured according to the technique proposed by Díaz-Castro et al. (2011). This method consists of the instant formation of oxidized glutathione, which is continuously reduced by an excess of glutathione reductase and NADPH present in the cuvette. The oxidation of NADPH to $\mathrm{NADP}^{+}$was monitored spectrophotometrically at $340 \mathrm{~nm}$. Cumen hydroperoxide was used as a substrate.

\subsection{Statistical Analysis}

The results were expressed as the mean \pm standard deviation (SD). The obtained data corresponded to data normally distributed and were statistically analyzed by one-way analysis of variance (ANOVA) followed by Tukey's test of multiple comparisons using Instat ${ }^{\circledR}$ software and the level of significance was set to $p<0.05$. The unilateral ANOVA test can also be used to evaluate multiple measures of the same variable taken on the same subjects or in combined individuals, either under different conditions or over more than two periods of time (Mishra et al., 2019).

\subsection{Ethics statement}

All in vivo experiments followed the ethical principles outlined for animal experimentation adopted by the Brazilian College of Animal Experimentation and were approved by the Ethical Committee for Animal Experimentation of UNIFAL-MG doc. $n^{\circ}$ 117/2007.

\section{RESULTS AND DISCUSSION}

Several studies have shown an increase in CK activity and oxidative stress in different tissues after intense muscle contractions (Paula et al., 2005; Huang et al., 2008; Chiang et al., 2009; Viana et al., 2012; Petersmann et al., 2016; Cheng et al., 2020). The reactive species 
produced in high concentration are responsible for an increase in oxidative stress markers, such as lipid peroxidation, protein carbonylation and DNA mutations that result in decreased muscle strength and muscle fatigue (Kawaura et al., 2018).

The FES protocol produces contractions by electrical stimulation, which depolarizes the motor nerve, producing a synchronous response in all motor units of the muscle. This synchronization promotes efficient contraction and stimulation with frequencies between 50 and $100 \mathrm{~Hz}$ that induces tetanic contractions (Berger et al., 2008). In the present study, it was noted that $48 \mathrm{~h}$ after completing FES at $100 \mathrm{~Hz}$, the activity of CK was significantly higher $(P=0.0006)$ in the exercise group $(589.17 \pm 61.07 \mathrm{U} / \mathrm{L})$ than in the control group $(285.14 \pm$ $46.78 \mathrm{U} / \mathrm{L})$.

In addition, FES induced a significant increase in superoxide production in neutrophils from rats submitted to exercise compared to the control group. Maximum superoxide production was observed 6 hours after FES (Figure 1A). This increase was prevented by drinking caffeinated instant coffee but not by decaffeinated instant coffee or caffeine alone (Figure 1B). Another study demonstrated that NADPH oxidase can be activated in resting neutrophils by strenuous exercise. NADPH oxidases produce ROS from molecular oxygen using NADPH as an electron donor (Chan et al., 2018). Levada-Pires et al. (2007) and Chan et al. (2018) showed that the exercise-induced production of reactive oxygen metabolites in neutrophils most likely occurred through the enhanced expression of p67phox and p47phox, the cytosolic components of the NADPH oxidase complex. Dong et al. (2011) observed an excessive activation of NADPH oxidase in rat neutrophils induced by overtraining. This result suggests that the activation of NADPH oxidase observed after exercise is related to the remarkable increase in the production of oxygen metabolites in phagocytic cells.
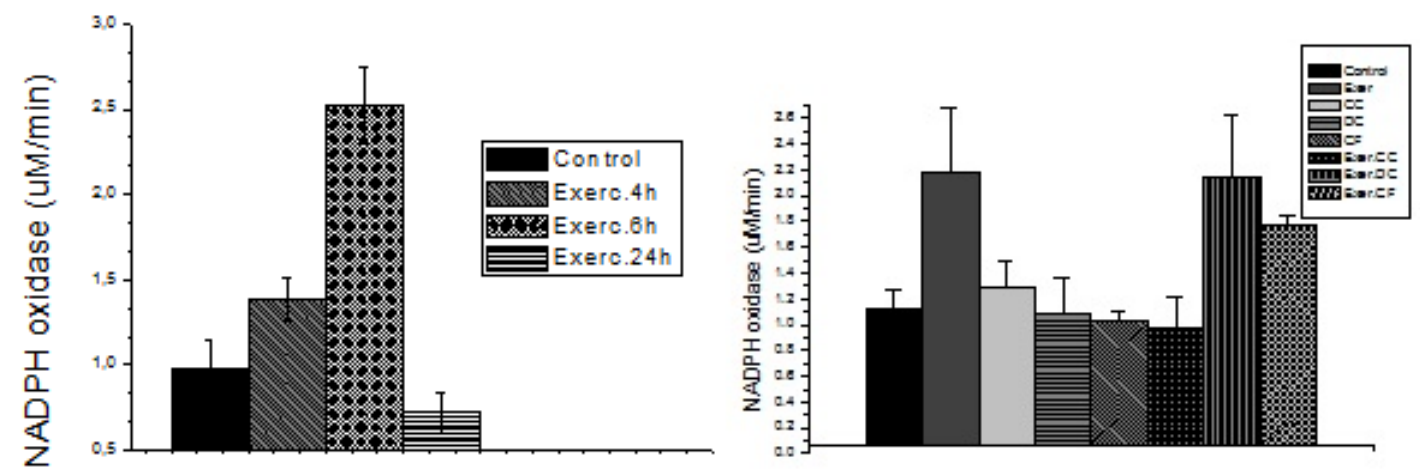

FIGURE 1. Quantification of NADPH system activity by the reduction of cytochrome C. A) After different times of the exercises. B) After consumption of caffeinated and decaffeinated instant coffee drinks and caffeine alone. Exerc and Exer: exercise, CC: caffeinated coffee, DC: decaffeinated coffee, CF: caffeine. The results were expressed as the mean \pm standard deviation (SD). The obtained data were statistically analyzed by one-way analysis of variance (ANOVA) followed by Tukey's test of multiple comparisons and the level of significance was set to $p<0.05$.

Two isoforms of NADPH oxidase are expressed in skeletal muscle such as NOX2 (located within the sarcolemma and T tubule) and NOX4 (present in the sarcoplasmic reticulum and mitochondria). NOX2 is characterized as a dominant source of ROS production mediated by NADPH oxidase in contracting muscles (Powers et al., 2020).

It is known that the $\mathrm{O}_{2}^{--}$produced during an oxidative burst can be rapidly converted to hydrogen peroxide $\left(\mathrm{H}_{2} \mathrm{O}_{2}\right)$ by the enzyme superoxide dismutase (Henriquez-Olguin et al., 2020). Myeloperoxidase is an enzyme found in the azurophilic granules of neutrophils that catalyzes the production of hypochlorous acid from hydrogen peroxide and chloride (Flannagan et al., 2012). However, no significant change was observed in myeloperoxidase activity (Figure 2), myeloperoxidase-independent pathways had utilized suggesting that the 
hydrogen peroxide produced from superoxide anions. Coffee and caffeine beverages had no significant effect on neutrophil myeloperoxidase activity.

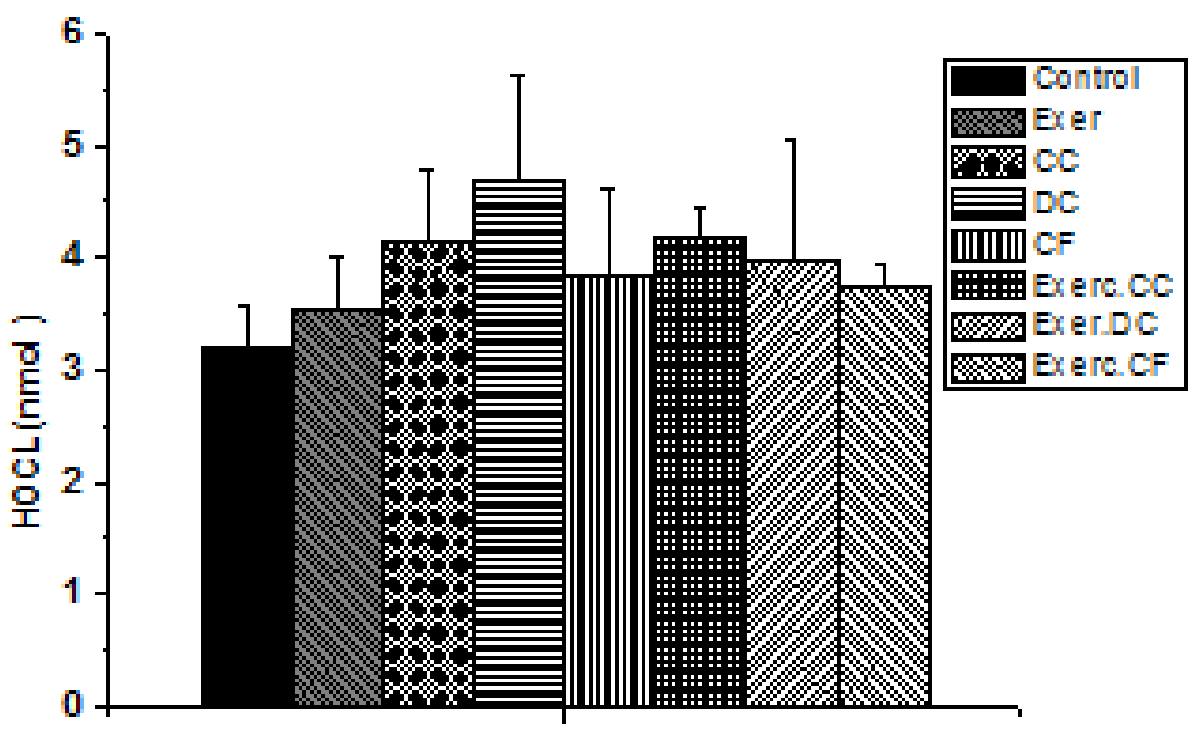

FIGURE 2. Determination of myeloperoxidase activity by $\mathrm{HOCl}$ formation test. Exerc and Exer: exercise, CC: caffeinated coffee, DC: decaffeinated coffee, CF: caffeine. The results were expressed as the mean \pm standard deviation (SD). The obtained data were statistically analyzed by one-way analysis of variance (ANOVA) followed by Tukey's test of multiple comparisons and the level of significance was set to $p<0.05$.

Thus, the effects of FES and coffee or caffeine on the oxidative burst were studied. SOD and GPx activities in peritoneal neutrophils were studied $6 \mathrm{~h}$ after FES (Table 1). The intracellular activity of superoxide dismutase and glutathione peroxidase protects cells against superoxide anions, hydrogen peroxide and lipid hydroperoxides. No significant change was observed in the activity of these enzymes in neutrophils after the exercise protocol was complete (Table 1). In our study, the administration of caffeinated coffee, decaffeinated coffee or caffeine did not change the activities of SOD and GPx in rat neutrophils.

Table 1. The effect of caffeinated and decaffeinated coffee on the superoxide dismutase and glutathione peroxidase activities in the neutrophils, six hours after exercise.

\begin{tabular}{ccc}
\hline Groups & SOD (U/mg prot.) $(\mathbf{n}=\mathbf{5})$ & GPx $(\mathbf{n m o l s}$ NADPH/g prot.) $(\mathbf{n}=\mathbf{5})$ \\
\hline Control $^{\mathbf{a}}$ & $0.367 \pm 0.082$ & $0.065 \pm 0.009$ \\
Exer $^{\mathbf{b}}$ & $0.528 \pm 0.053$ & $0.075 \pm 0.013$ \\
CC $^{\mathbf{c}}$ & $0.320 \pm 0.035$ & $0.065 \pm 0.011$ \\
CD $^{\mathbf{d}}$ & $0.398 \pm 0.070$ & $0.072 \pm 0.023$ \\
CF $^{\mathbf{e}}$ & $0.337 \pm 0.042$ & $0.045 \pm 0.013$ \\
Exer.CC $^{\mathbf{f}}$ & $0.390 \pm 0.065$ & $0.076 \pm 0.012$ \\
Exer.CDg $^{\text {Exer.CF }}$ & $0.478 \pm 0.054$ & $0.077 \pm 0.011$ \\
\hline
\end{tabular}

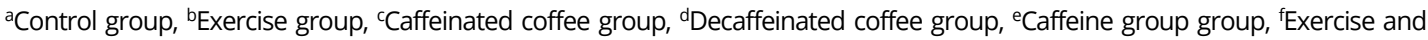
caffeinated coffee group, gExercise and decaffeinated coffee group, hExercise and caffeine group. SOD: Superoxide dismutase; GPx: Glutathione peroxidase; NADPH: reduced nicotinamide adenine dinucleotide phosphate; Prot:: Protein. 
There are conflicting reports in the literature regarding the activity of enzymes such as SOD and GPx after physical exercise. These conflicting data could be attributed to the different exercise protocols used in these studies; the body's response to exercise is highly dependent on factors such as the type, duration and intensity of the exercise performed (Margonis et al., 2007, Muñoz et al., 2010). Although there are other antioxidants that were not analyzed in this work (catalase, thioredoxin, peroxiredoxin and reduced glutathione), SOD and GPx are the body's first line of defense used to reduce the adverse effects of oxidative stress (LimónPacheco \& Gonsebatt, 2009; Kawaura et al., 2018; Powers et al., 2020).

The results obtained in this study suggest that the activity of these antioxidant enzymes was not activated in a manner proportional to the need induced by the pro-oxidant events. Physical exercise promotes an increase in blood flow that exposes endothelial cells to stress and triggers an increase in the production of nitric oxide (NO). The increase in oxygen consumption (increase the 100-fold) or hypoxia during physical activity induces an increase in the production of the superoxide anion radical (Tsai et al., 2001; Paula et al., 2005; Chiang et al., 2009; Zlatkovic et al., 2011; Henriquez-Olguin et al., 2020; Thirupathi et al., 2020).

Muscle contractions contribute to the increase of $\mathrm{NO}$ production in the contraction fibers (Powers et al., 2020). NO interacts quickly with the superoxide anion leading to the formation of peroxynitrite (ONOO-), a highly reactive species capable of inducing the depletion of thiol groups and nitration of proteins, lipids and DNA, reducing NO bioavailability and increasing the oxidative process. This fact could explain the absence of an increase in myeloperoxidase, superoxide dismutase and glutathione peroxidase activities in neutrophils from the group of animals subjected to an intense exercise protocol (Förstermann \& Sessa, 2012; HenriquezOlguin et al., 2020; Powers et al., 2020).

In these situations, therapeutic intervention with dietary supplementation becomes important to prevent the degradation of biologically active molecules (Paredes-López et al., 2010; Shahidi \& Zhong, 2010; Lattanzio et al., 2009; Yfanti et al., 2019). The data collected in this study show that drinking caffeinated instant coffee prevented an increase in NADPH oxidase-mediated superoxide production induced by highly intense exercise in rat neutrophils. Several studies have associated the increased production of superoxide anion in neutrophils with the development of some diseases (Kvietys \& Granger, 2011). Thus, these results corroborate published data showing that drinking caffeinated instant coffee has an antioxidant effect in vivo both in animals and in humans (Natella et al., 2007; Duarte et al., 2009; Neto et al., 2010; Carvalho et al., 2011; Choi et al., 2011; Abreu et al., 2011; Viana et al., 2012), and suggest that caffeinated instant coffee can modulate NADPH oxidase activity in rat peritoneal neutrophils. This action may be due to the presence of chlorogenic acid, the main bioactive component of coffee, which inhibits the activity of NADPH oxide through its potent antioxidant action (Belviso \& Barbosa-Pereira, 2019). More studies need to be conducted to further information on these mechanisms of action.

In contrast, it was observed that drinking decaffeinated instant coffee or caffeine solution alone had no significant effect on superoxide production in the neutrophils of the animals studied. These results allow us to suggest that despite the boost to physical performance provided by caffeine consumption, as reported by some authors, caffeine alone (when administered in doses similar to those found in caffeinated coffee drinks) is not able to prevent an increase in superoxide production induced by intense exercise (Altimari et al., 2006; Astorino \& Roberson, 2010). There is contrasting evidence regarding the contribution of caffeine to the antioxidant capacity of coffee. Although some studies found a high antioxidant activity with phenolic compounds but not caffeine, others indicate that caffeine provides a substantial contribution to the antioxidant properties of coffee (Brezová et al., 2009; Olcina et al., 2008).

It is important to highlight that in addition to caffeine and other methylxanthines, coffee beverages contain hundreds of other antioxidant compounds, such as flavonoids and chlorogenic acid. The latter represent approximately $6-10 \%$ of the dry weight of the coffee. Different methods of processing and roasting (with variation in temperature and time) the beans and preparing the beverage may influence the chemical composition of coffee, 
especially the concentration of phenolic compounds present in the drink (Daglia et al., 2000; Lima et al., 2010; Kwak et al., 2017). The roasting process contributes to a reduction in the content of chlorogenic acid of $8-10 \%$ and $11-45 \%$ of polyphrnols and consequently in the antioxidant potential (Kwak et al., 2017; Zain et al., 2018). It is known that the decaffeination process induces a loss of 5-caffeoylquinic acid in brewed coffee due to the formation of a complex between this compound and caffeine (Toci et al., 2006). Duarte et al. (2009) found that the decaffeination of coffee with dichloromethane reduces the antioxidant potential of coffee in vitro. These data could explain the different effects observed between caffeinated and decaffeinated instant coffees on superoxide anion production induced by strenuous exercise in rat neutrophils. The exact mechanism by which caffeinated instant coffee acts as an antioxidant is not fully understood. Based on published data and our results, we suggest that this activity is associated with the chemical composition and concentration of phenolic compounds and other antioxidant substances formed during roasting (Toci et al., 2006; Duarte et al., 2009). These compounds are most likely formed by Maillard and melanoidin reactions with which the decaffeination process can interfere, thereby reducing the ability of decaffeinated coffee to inhibit NADPH oxidase (Limón-Pacheco \& Gonsebatt, 2009).

Despite suggestions that some flavonoids may inhibit the oxidative burst of phagocytes via various mechanisms, the complexity of coffee's chemical spectrum makes it difficult to elucidate which factors are responsible for this effect. Therefore, more research must be performed to elucidate the mechanism of action of caffeinated coffee on NADPH oxidase in neutrophils.

\section{CONCLUSION}

From the results obtained, we conclude that the exercise protocol adopted herein stimulated NADPH oxidase-mediated superoxide production in neutrophils in the animals we studied. Neither decaffeinated instant coffee nor caffeine solution had an effect on the respiratory burst of neutrophils. Caffeinated instant coffee intake did not induce changes in myeloperoxidase and antioxidant enzyme activities, but it was able to prevent the increase of NADPH oxidase-mediated superoxide production in rat neutrophils. Moderate intake of caffeinated instant coffee (equivalent to a daily human consumption of $450-\mathrm{mL}$ cups of coffee) may have beneficial effects on health, contributing to a reduction in superoxide anion production triggered in neutrophils by high-intensity exercise. Thus, our results support the beneficial effects of the coffee beverage on health, and suggest its potential use as a functional beverage against oxidative damage induced by high-intensity exercise.

\section{ACKNOWLEDGEMENTS}

This work was supported by grants from the Fundação de Amparo à Pesquisa do Estado de Minas Gerais, FAPEMIG, Brazil and Coordenação de Aperfeiçoamento de Pessoal de Nível Superior, CAPES, Brazil.

\section{REFERENCES}

Abreu RV, Silva-Oliveira EM, Moraes MFD, Pereira GS, Moraes-Santos T. Chronic and caffeine ingestion effects on the cognitive function and antioxidant system of rat brains. Pharmacol Biochem Behav. 2011;99(4):659-64. http://dx.doi.org/10.1016/j.pbb.2011.06.010. PMid:21693129.

Altimari LR, Moraes AC, Tirapegui JO, Moreau RLM. Caffeinne and performance in aerobic exercise. Braz J Pharm Sci. 2006;42:17-27. http://dx.doi.org/10.1590/S1516-93322006000100003.

Astorino T, Roberson DW. Efficacy of acute caffeine ingestion for short-term high-intensity exercise performance: A systematic review. J Strength Cond Res. 2010;24: 257-265. https:// doi: 10.1519/JSC.0b013e3181c1f88a

Babior BM. Phagocytes and Oxidative Stress. Am J Med. 2000;109(1):33-44. http://dx.doi.org/10.1016/S0002-9343(00)00481-2. PMid:10936476. 
Belviso S, Barbosa-Pereira L. Chapter 3.9 - Coffee Supplements. In: SM Nabavi, AS Silva. Nonvitamin and nonmineral nutritional supplements. Cambridge, Massachusetts: Academic Press; 2019. p. 177-85. http://dx.doi.org/10.1016/B978-0-12-812491-8.00025-4

Berger TW, Chapin JK, Gerhardt GA, McFarland DJ, Principe JC, Soussou WV, Taylor DM, Tresco PA. Braincomputer interfaces. An international assessment of research and development trends. New York. Springer Science \& Business Media BV; 2008.

Brezová V, Slebodová A, Stasko A. Coffee as a source of antioxidants: na EPR study. Food Chem. 2009;114(3):859-68. http://dx.doi.org/10.1016/j.foodchem.2008.10.025.

Burtis CA, Ashwood ER, Bruns D. Tietz textbook of clinical chemistry. 3nd. ed. Philadelphia: W.B. Saunders Company; 2008.

Carvalho DC, Brigagão MR, dos Santos MH, de Paula FB, Giusti-Paiva A, Azevedo L. Organic and conventional Coffea arabica L.: A comparative study of the chemical composition and physiological, biochemical and toxicological effects in Wistar rats. Plant Foods Hum Nutr. 2011;66(2):114-21. http://dx.doi.org/10.1007/s11130-011-0221-9. PMid:21523414.

Chan S, Hung C, Shih J, Chu P, Cheng Y, Lin H, Hsieh P, Tsai K. Exercice intervention attenuates hyperhomocysteinemia-induced aortic endothelial oxidative injury by regulating SIRT1 through mitigating NADPH oxidase/LOX-1 signaling. Redox Biol. 2018;14:116-25. http://dx.doi.org/10.1016/j.redox.2017.08.016. PMid:28888894.

Cheng AJ, Jude B, Lanner JT. Intrauscular mechanisms of overtraining. Redox Biol. 2020;35:101480. http://dx.doi.org/10.1016/j.redox.2020.101480. PMid:32179050.

Chiang J, Shen YC, Wang YH, Hou YC, Chen CC, Liao JF, Yu MC, Juan CW, Liou KT. Honokiol protects rats against eccentric exercise-induced skeletal muscle damage by inhibiting NF-k $\beta$ induced oxidative stress and inflammation. Eur J Pharmacol. 2009;610(1-3):119-27. http://dx.doi.org/10.1016/j.ejphar.2009.03.035. PMid:19303869.

Choi E, Park S, Cho Y. Freeze-dried instant coffee can promote the activities of antioxidant enzymes and induce weight loss but also aggravate the plasma cholesterol profile in rats. Nutr. 2011;27(1112):1202-5. http://dx.doi.org/10.1016/j.nut.2011.02.003. PMid:21621391.

Ciz M, Denev P, Kratchanova M, Vasicek O, Ambrozova G, Lojek A. Flavonoids Inhibit the Respiratory Burst of Neutrophils in Mammals. Oxid Med Cell Longev. 2012;181295:181295. http://dx.doi.org/10.1155/2012/181295. PMid:22577489.

Daglia M, Papetti A, Gregotti C, Berté F, Gazzani G. In vitro antioxidant and ex vivo protective activities of green and roasted coffee. J Agric Food Chem. 2000;48(5):1449-54. http://dx.doi.org/10.1021/jf990510g. PMid:10820041.

Dallo MAL. Consideraciones actuales sobre el consumo de café em la actividad física y el deporte. Aten Prim. 2009;41(12):698-701. http://dx.doi.org/10.1016/j.aprim.2009.09.014.

Díaz-Castro J, Ojeda ML, Alférez MJM, López-Aliaga I, Nestares T, Campos MS. Se bioavailability and glutathione peroxidase activity in iron deficiente rats. J Trace Elem Med Biol. 2011;25(1):42-6. http://dx.doi.org/10.1016/j.jtemb.2010.12.005. PMid:21277180.

Dong J, Chen P, Wang R, Yu D, Zhang Y, Xiao W. NADPH Oxidase: A target for the modulation of the excessive oxidase damage induced by overtraining in rat neutrophils. Int J Biol Sci. 2011;7(6):88191. http://dx.doi.org/10.7150/ijbs.7.881. PMid:21814483.

Duarte SMS, Abreu CMP, Menezes HC, Paula FBA, Pereira RGFA, Gouvêa CMCP. Efeito da bebida de café descascado sobre a atividade antioxidante, os parâmetros hematológicos e bioquímicos em ratos. Ciência Tecnol Alime. 2009;29(4):703-8. http://dx.doi.org/10.1590/S0101-20612009000400001.

Ferreira CS, Araújo TH, Ângelo ML, Pennacchi PC, Okada SS, Paula FBA, Migliorini S, Rodrigues MR. Neutrophil dysfunction induced by hyperglycemia: modulation of myeloperoxidase activity. Cell Biochem Funct. 2012;30(7):604-10. http://dx.doi.org/10.1002/cbf.2840. PMid:22610543.

Flannagan RS, Jaumouillé V, Grinstein S. The cell biology of phagocytosis. Annu. Rev Pathol-Mech. 2012;7:49-86. http://dx.doi.org/10.1146/annurev-pathol-011811-132445. PMid:21910624.

Förstermann U, Sessa WC. Nitric oxide synthases: regulation and function. Eur Heart J. 2012;33(7):82937, 837a-837d. http://dx.doi.org/10.1093/eurheartj/ehr304. PMid:21890489.

Frost-Meyer NJ, Logomarsino JV. Impact of coffee components on inflammatory markers: A review. J Funct Foods. 2012;4(4):819-30. http://dx.doi.org/10.1016/j.jff.2012.05.010.

Henriquez-Olguin C, Meneses-Valdes R, Jensen TE. Compartimentalized muscle redox signals controlling exercise metabolism - Current state, future challenges. Redox Biol. 2020;35:101473. http://dx.doi.org/10.1016/j.redox.2020.101473. PMid:32122793. 
Huang CC, Tsai CC, Lin WT. Potential ergogenic effects of L-arginine against oxidative and inflammatory stress induced by acute exercise in aging rats. J Gerontol. 2008;43(6):571-7. http://dx.doi.org/10.1016/j.exger.2008.03.002. PMid:18424033.

Jones OT, Hancock T. Assays of plasma membrane NADPH oxidase. Methods Enzymol. 1994;233:222-9. http://dx.doi.org/10.1016/S0076-6879(94)33025-5. PMid:8015459.

Kain V, Halade GV. Role of neutrophils in ischemic heart failure. Pharmacol Ther. 2020;205:107424. http://dx.doi.org/10.1016/j.pharmthera.2019.107424. PMid:31629005.

Kalschne DL, Viegas C, De Conti AJ, Corso MP, Benassi MT. Effect of steam treatment on the profile of bioactive compounds and antioxidant activity of defective roasted coffee (Coffea canephora). Lebensm Wiss Technol. 2019;99:364-70. http://dx.doi.org/10.1016/j.Iwt.2018.09.080.

Kawaura T, Fujii R, Li X, Higashida K, Muraoka I. Effects of exhaustive exercises, with different intensities, on oxidative stress markers in rat plasma and skeletal muscle. Sci Sports. 2018;33(3):169-75. http://dx.doi.org/10.1016/j.scispo.2017.08.008.

Kettle AJ, Winterbourn CC. Assays for the chlorination activity of myeloperoxidase. Methods Enzymol. 1994;233:502-13. http://dx.doi.org/10.1016/S0076-6879(94)33056-5. PMid:8015486.

Kotyczka C, Boettler U, Lang R, Stiebitz H, Bytof G, Lantz I, Hofmann T, Marko D, Somoza V. Dark roast coffee is more effective than light roast coffee in reducing body weight, and in restoring red blood cell vitamin $\mathrm{E}$ and glutathione concentrations in healthy volunteers. Mol Nutr Food Res. 2011;55(10):1582-6. http://dx.doi.org/10.1002/mnfr.201100248. PMid:21809439.

Kvietys PR, Granger DN. Role of reactive oxygen and nitrogen species in the vascular responses to inflammation. Free Radic Biol Med. 2011;52(3):556-92. http://dx.doi.org/10.1016/j.freeradbiomed.2011.11.002. PMid:22154653.

Kwak HS, Ji S, Jeong Y. The effect of air flow in coffee roasting for antioxidant activity and total polyphenol content. Food Control. 2017;71:210-6. http://dx.doi.org/10.1016/j.foodcont.2016.06.047.

Lattanzio V, Kroon PA, Linsalata V, Cardinali A. Globe artichoke: A functional food and source of nutraceutical ingredients. J Funct Foods. 2009;1(2):131-44. http://dx.doi.org/10.1016/j.jff.2009.01.002.

Levada-Pires AC, Lambertucci RH, Mohamad M, Hirabara SM, Curi R, Pithon-Curi TC. Exercise training raises expression of the cytosolic components of $\mathrm{NADPH}$ oxidase in rat neutrophils. Eur J Appl Physiol. 2007;100(2):153-60. http://dx.doi.org/10.1007/s00421-007-0414-y. PMid:17310390.

Lima AR, Pereira RGFA, Abrahão AS, Duarte SMS, Paula FBA. Compostos bioativos do café: atividade antioxidante in vitro o café verde e torrado antes e após a descafeinização. Quim Nova. 2010;33(1):20-4. http://dx.doi.org/10.1590/S0100-40422010000100004.

Limón-Pacheco J, Gonsebatt ME. The role of antioxidants and antioxidant-related enzymes in protective responses to environmentally induced oxidative stress. Mutat Res Genet Toxicol Environ Mutagen. 2009;674(1-2):137-47. http://dx.doi.org/10.1016/j.mrgentox.2008.09.015. PMid:18955158.

Liu Y, Kitts DD. Confirmation that the Maillard reaction is the principle contributor to the antioxidant of coffee brews. Food Res Int. 2011;44(8):2418-24. http://dx.doi.org/10.1016/j.foodres.2010.12.037.

Luczaj W, Gęgotek A, Skrzydlewska E. Antioxidants and HNE in redox homeostasis. Free Radic Biol Med. 2017;111:87-101. http://dx.doi.org/10.1016/j.freeradbiomed.2016.11.033. PMid:27888001.

Margonis K, Fatouros IG, Jamurtas AZ, Nikolaidis MG, Douroudos I, Chatzinikolaou A, Mitrakou A, Mastorakos G, Papassotiriou I, Taxildaris K, Kouretas D. Oxidative stress biomarkers responses to physical overtraining: implications for diagnosis. Free Radic Biol Med. 2007;43(6):901-10. http://dx.doi.org/10.1016/j.freeradbiomed.2007.05.022. PMid:17697935.

Mirończuk-Chodakowska I, Witkowska AM, Zujko ME. Endogenous non-enzymztic antioxidants in the human body. Adv Med Sci. 2018;63(1):68-78. http://dx.doi.org/10.1016/j.advms.2017.05.005. PMid:28822266.

Mishra P, Singh U, Pandey CM, Mishra P, Pandey G. Application of student's t-test, analysis of variance, and covariance. Ann Card Anaesth. 2019;22(4):407-11. http://dx.doi.org/10.4103/aca.ACA_94_19. PMid:31621677.

Moreira MEC, Pereira RGFA, Dias DF, Gontijo VS, Vilela FC, Moraes GOI, Giusti-Paiva A, Santos MH. Antiinflammatory effect of aqueous extracts of roasted and green Coffea arabica L. J Funct Foods. 2013;5(1):466-74. http://dx.doi.org/10.1016/j.jff.2012.12.002.

Muñoz ME, Galan Al, Palacios E, Diez MA, Muguerza B, Cobaleda C, Calvo Jl, Aruoma Ol, Sanchez-Garcia I, Jimenez R. Effect of an antioxidant functional food beverage on exercise-induced oxidative stress: 
A long-term and large-scale clinical intervention study. Toxicol. 2010;278(1):101-11. http://dx.doi.org/10.1016/j.tox.2009.10.015. PMid:19857542.

Natella F, Nardini M, Belelli F, Scaccini C. Coffee drinking induces incorporation of phenolic acids into LDL and increases the resistance of DLD to ex vivo oxidation in humans. Am J Clin Nutr. 2007;86(3):604-9. http://dx.doi.org/10.1093/ajcn/86.3.604. PMid:17823423.</jrn>

Neto YAH, Rocha BA, Pedroso RN, Neto MMF, Paula FBA, Duarte SMS. Protective effects of roasted coffee drinl on liver function of cirrhotic rats. J Nat Pharm. 2010;1(1):19-23. http://dx.doi.org/10.4103/2229-5119.73582.

O'Keefe JH, Bhatti SK, Patil HR, DiNicolantonio JJ, Lucan SC, Lavie CJ. Effects of habitual coffee consumption on cardiometabolic disease, cardiovascular health, and all-cause mortality. J Am Coll Cardiol. 2013;62(12):1043-51. http://dx.doi.org/10.1016/j.jacc.2013.06.035. PMid:23871889.

Olas B, Bryś M. Effects of coffee, energy drinks and their components on hemostasis: the hypothetical mechanisms of their action. Food Chem Toxicol. 2019;127:31-41. http://dx.doi.org/10.1016/j.fct.2019.02.039. PMid:30844438.

Olcina GJ, Timón R, Muñoz D, Maynar Jl, Caballero MJ, Maynar M. Caffeine ingestion on oxidative stress in a steady-state test at 75\% $\mathrm{VO}_{2 \max }$. Sci Sports. 2008;23(2):87-90. http://dx.doi.org/10.1016/j.scispo.2007.10.005.

Oyanagui Y. Reevaluation of assay methods and establishment of kit for superoxide dismutase activity. Anal Biochem. 1984;142(2):290-6. http://dx.doi.org/10.1016/0003-2697(84)90467-6. PMid:6099057.

Paredes-López O, Cervantes-Ceja ML, Vigna-Pérez M, Hernández-Pérez T. Berries: improving human health and healthy aging, and promoting quality life - A Review. Plant Foods Hum Nutr. 2010;65(3):299-308. http://dx.doi.org/10.1007/s11130-010-0177-1. PMid:20645129.

Parras $\mathrm{P}$, Martínez-Tomé M, Jiménez AM, Murcia MA. Antioxidant capacity of coffees of several origins brewed following three different produces. Food Chem. 2007;102(3):582-92. http://dx.doi.org/10.1016/j.foodchem.2006.05.037.

Paula FBA, Gouvêa CMCP, Alfredo PP, Salgado I. Protective action of a hexane crude extract of Pterodon emarginatus fruits against oxidative and nitrosative stress induced by acute exercise in rats. BMC Complement Altern Med. 2005;5(1):17. http://dx.doi.org/10.1186/1472-6882-5-17. PMid:16107219.

Pereira GVM, Neto DPC, Magalhães Júnior Al, do Prado FG, Pagnoncelli MGB, Karp SG, Soccol CR. Chapter Three - Chemical composition and health properties of coffee and coffee by-products. In: Toldrá F. Advances in food and nutrition research. Spain: Academic Press; 2020. v.91, p. 65-96. https://doi.org/10.1016/bs.afnr.2019.10.002

Petersmann A, Ittermann T, Frieß C, Lubenow N, Kohlmann T, Greinacher A, Masuch A, Nauck M. Impact of physical activity of individuals and creatine kinase on $99^{\text {th }}$ percentiles of troponin I assays. Clin Chim Acta. 2016;462(1):187-92. http://dx.doi.org/10.1016/j.cca.2016.10.002. PMid:27712987.

Powers SK, Deminice R, Ozdemir M, Yoshihara T, Bomkamp MP, Hyatt H. Exercise-induced oxidative stress: friend or Foe? J Sport Health Sci. 2020;9(5):415-25. http://dx.doi.org/10.1016/j.jshs.2020.04.001. PMid:32380253.

Powers SK, Jackson MJ. Exercise-induced oxidative stress: cellular mechanisms and impact on muscle force production. Physiol Rev. 2008;88(4):1243-76. http://dx.doi.org/10.1152/physrev.00031.2007. PMid:18923182.

Ramalakshmi K, Raghavan B. Caffeine in coffee: Its removal. Why and How? Crit Rev Food Sci Nutr. 1999;39(5):441-56. http://dx.doi.org/10.1080/10408699991279231. PMid:10516914.

Rocha BA, Pedroso RN, Neto MMF, Paula FBA, Duarte SMS, Neto YAH. Protective effects of roasted coffee drink on liver function of cirrhotic rats. J. Nat. Pharm. 2010;1(1):19-23. http://dx.doi.org/10.4103/2229-5119.73582.

Ruangthai R, Phoemsapthawee J. Combined exercise training improves blood pressure and antioxidant capacity in elderly individuals with hypertension. J Exerc Sci Fit. 2019;17(2):67-76. http://dx.doi.org/10.1016/j.jesf.2019.03.001. PMid:30949214.

Shahidi F, Zhong Y. Novel antioxidants in food quality preservation and health Promotion. Eur J Lipid Sci Technol. 2010;112(9):930-40. http://dx.doi.org/10.1002/ejlt.201000044.

Sinet PM, Michelson AM, Bazin A, Lejeune J, Jerome H. Increase in glutathione peroxidase activity in erythrocytes from trisomy 21 subjects. Biochem Biophys Res Commun. 1975;67(3):910-5. http://dx.doi.org/10.1016/0006-291X(75)90763-9. PMid:1201081. 
Stefanello N, Spanevello RM, Passamonti S, Porciúncula L, Bonan CD, Olabiyi AA, Teixeira da Rocha JB, Assmann CE, Morsch VM, Schetinger MRC. Coffee, caffeine, chlorogenic acid, and the purinergic system. Food Chem Toxicol. 2019;123:298-313. http://dx.doi.org/10.1016/j.fct.2018.10.005. PMid:30291944.

Thirupathi A, Pinho RA, Chang Y-Z. Physical exercise: an inducer of positive oxidative stress in skeletal muscle aging. Life Sci. 2020;252:117630. http://dx.doi.org/10.1016/j.lfs.2020.117630. PMid:32294473.

Toci A, Farah A, Trugo LC. Efeito do processo de descafeinação com diclorometano sobre a composição química dos cafés arábica e robusta antes e após a torração. Quim Nova. 2006;29(5):965-71. http://dx.doi.org/10.1590/S0100-40422006000500015.

Tripetch P, Borompichaichartkul C. Effect of packaging materials and storage time on changes of colour, phenolic content, chlorogenic acid and antioxidant activity in Arabica green coffee beans (Coffea Arabica L. CV. Catimor). J Stored Prod Res. 2019;84:101510. http://dx.doi.org/10.1016/j.jspr.2019.101510.

Tsai K, Hsu T, Hsu K, Cheng H, Liu T, Hsu C, Kong C. Oxidative DNA damage in human peripheral leukocytes induced by massive aerobic exercise. Free Radic Biol Med. 2001;31(11):1465-72. http://dx.doi.org/10.1016/S0891-5849(01)00729-8. PMid:11728819.

Viana ALM, Fonseca MDM, Meireles ELJ, Duarte SMS, Rodrigues MR, Paula FBA. Effects of the consumption of caffeinated and decaffeinated instant coffee beverages on oxidative stress induced by strenuous exercise in rat. Plant Foods Hum Nutr. 2012;67(1):82-7. http://dx.doi.org/10.1007/s11130-011-0267-8. PMid:22173821.

Vignoli JA, Bassoli DG, Benassi MT. Antioxidant activity, caffeine and melanoidins in soluble coffee: the influence of processing conditions and raw material. Food Chem. 2011;124(3):863-8. http://dx.doi.org/10.1016/j.foodchem.2010.07.008.

Vilela FMP, Fonseca YM, Jabor JR, Vicentini FTMC, Fonseca MJV. Effect of ultraviolet filters on skin superoxide dismutase activity in hairless mice after a single dose of ultraviolet radiation. Eur J Pharm Biopharm. 2012;80(2):387-92. http://dx.doi.org/10.1016/j.ejpb.2011.10.005. PMid:22036989.

Warraich UE, Hussain F, Kayani HUR. Aging - Oxidative stress, antioxidants and computational modeling. Heliyon. 2020;6(5):e04107. http://dx.doi.org/10.1016/j.heliyon.2020.e04107. PMid:32509998.

Yfanti C, Deli CK, Georgakouli K, Fatouros I, Jamurtas AZ. Sport nutrition, redox homeostasis and toxicity in sport performance. Curr Opin Toxicol. 2019;13:45-67. http://dx.doi.org/10.1016/j.cotox.2019.01.003.

Zain MZM, Baba AS, Shori AB. Effect of polyphenols enriched from green coffee bean on antioxidant activity and sensory evaluation of bread. J Kind Saud Univ Sci. 2018;30:278-82. http://dx.doi.org/10.1016/j.jksus.2017.12.003.

Zlatkovic M, Jakovljevic V, Stanojlovic O, Djuric D. 586 Interplay between nitric oxide and superoxide anion radical during progressive exercise in elite soccer players. Atheroscler Suppl. 2011;12(1):124. http://dx.doi.org/10.1016/S1567-5688(11)70587-6.

\section{Authors' contributions}

EMLJ, ALMV, MDMF and MLA performed the experiments, collected and analyzed the data; BCCS analyzed the data; SMSD, MRR and FBAP designed the study and wrote the paper; SAF analysis and evaluation of data, and wrote the paper.

The study was carried out at Federal University of Alfenas - UNIFAL-MG, Alfenas, Minas Gerais, Brazil. 